\title{
Nasal Immunization with the C-Terminal Domain of Bcla3 Induced Specific IgG Production and Attenuated Disease Symptoms in Mice Infected with Clostridioides difficile Spores
}

\author{
Ana Raquel Maia ${ }^{1}$, Rodrigo Reyes-Ramírez ${ }^{2,3}$, Marjorie Pizarro-Guajardo ${ }^{2,3}$, Anella Saggese ${ }^{1}$, \\ Ezio Ricca ${ }^{1}$, Loredana Baccigalupi ${ }^{4, *}$ and Daniel Paredes-Sabja ${ }^{2,3,5, *(1)}$ \\ 1 Dipartimento di Biologia, Università di Napoli Federico II, Via Cinthia 26, 80126 Napoli, Italy; \\ raqueldiasmaia@outlook.com (A.R.M.); ornellasaggese2010@libero.it (A.S.); ericca@unina.it (E.R.) \\ 2 Microbiota-Host Interactions and Clostridia Research Group, Departamento de Ciencias Biológicas, \\ Facultad de Ciencias de la Vida, Universidad Andrès Bello, Avenida Republica 330, Santiago 8370186, Chile; \\ rodrigoreyesr1992@gmail.com (R.R.-R.); marjorie.pizarrog@gmail.com (M.P.-G.) \\ 3 Millennium Nucleus in the Biology of Intestinal Microbiota, Avenida Republica 330, Santiago 8370186, Chile \\ 4 Dipartimento di Medicina Molecolare e Biotecnologie Mediche, Università di Napoli Federico II, \\ Via Pansini 5, 80131 Napoli, Italy \\ 5 Department of Biology, Texas A\&M University, College Station, TX 77843, USA \\ * Correspondence: lorbacci@unina.it (L.B.); dparedes-sabja@bio.tamu.edu (D.P.-S.)
}

Received: 4 June 2020; Accepted: 16 July 2020; Published: 13 September 2020

\begin{abstract}
Clostridioides difficile is a Gram-positive, spore-forming bacterium that causes a severe intestinal infection. Spores of this pathogen enter in the human body through the oral route, interact with intestinal epithelial cells and persist in the gut. Once germinated, the vegetative cells colonize the intestine and produce toxins that enhance an immune response that perpetuate the disease. Therefore, spores are major players of the infection and ideal targets for new therapies. In this context, spore surface proteins of $C$. difficile, are potential antigens for the development of vaccines targeting $C$. difficile spores. Here, we report that the $C$-terminal domain of the spore surface protein $\mathrm{BclA} 3, \mathrm{BclA} 3_{\mathrm{CTD}}$, was identified as an antigenic epitope, over-produced in Escherichia coli and tested as an immunogen in mice. To increase antigen stability and efficiency, $\mathrm{BclA} 3_{\mathrm{CTD}}$ was also exposed on the surface of $B$. subtilis spores, a mucosal vaccine delivery system. In the experimental conditions used in this study, free BclA3 ${ }_{\text {CTD }}$ induced antibody production in mice and attenuated some $C$. difficile infection symptoms after a challenge with the pathogen, while the spore-displayed antigen resulted less effective. Although dose regimen and immunization routes need to be optimized, our results suggest $\mathrm{BclA}{ }_{\mathrm{CTD}}$ as a potentially effective antigen to develop a new vaccination strategy targeting C. difficile spores.
\end{abstract}

Keywords: mucosal vaccine; exosporium proteins; Bacillus subtilis; immune response; Clostridium difficile; gastrointestinal infection; recombinant spores

\section{Introduction}

Clostridioides difficile is a Gram-positive, spore-forming and obligate anaerobe gastrointestinal bacterium, responsible for the most common nosocomial infection in industrialized countries [1]. In recent years the incidence and severity of $C$. difficile infections (CDI) has increased worldwide due to the emergence of antibiotic-resistant and hyper-virulent strains. According to the Centers for Disease Control and Prevention (CDC) in 2017 there were an estimated 223,900 cases in hospitalized 
patients and 12,800 deaths in the United Stated by CDI [2]. Elderly people and frequent hospitalized patients have been notified as the groups of major risk to develop CDI [3]. In addition, about $20 \%$ of the infected people develop a second CDI episode within 2 months and in the case of more than two episodes, the frequency of further recurrences increases dramatically up to $60 \%$ [4-6]. Nowadays, CDI is not only a major concern, but also an economic burden. Recent data indicated that CDI is more common than methicillin-resistant Staphylococcus aureus infections [7] and estimated a cost per CDI episode ranging from EUR 5000 to 12,000 in the European Union [8] and approximately USD 21,000 in the United States [9].

CDI is mainly transmitted by $C$. difficile spores through the fecal-oral route. Ingested spores survive the transit through the stomach, interact with intestinal epithelial cells and persist in the host gut. When gut conditions are favorable, i.e., when the number of other members of the gut microbiota is severely reduced, $C$. difficile spores germinate and massively colonize the gut. Growing cells of $C$. difficile then produce virulence factors that induce a strong immune response and the symptoms associated to $C$. difficile infections $[10,11]$. Being infection vehicles, mediators of the initial interaction with intestinal cells and responsible of the persistence of the pathogen in the animal gut [12], C. difficile spores are key players of CDI and ideal targets of anti-C. difficile therapeutic treatments.

It is known that the hydrophobicity of $C$. difficile spores, due to the proteinaceous exosporium, contributes to adhesion to hospital surfaces and to intestinal epithelial cells (IECs) $[13,14]$ and members of the BclA family of collagen-like glycoproteins are abundantly present in the $C$. difficile exosporium. In the hyper-virulent strain R20291 of $C$. difficile the BclA proteins showed $56 \%$ similarity with the BclA protein of Bacillus anthracis [15], known to be highly immunogenic and to act as spore surface ligand for the $\alpha 2 \beta 1$ integrin present in IECs, driving spore entry into the epithelial barrier [16]. Further investigation needs to be done in order to fully understand the role of BclA proteins in C. difficile spores; however, evidence suggest that these proteins are involved in the formation of the hair-like projections in most $C$. difficile strains such as the hyper-virulent strain R20291 [17,18] and their spore surface location propose them as potential antigens [19]. While the antigenicity of BclA1 and BclA2 has been recently tested [20-23], BclA3 has not been directly evaluated to date.

The $C$. difficile collagen-like BclA3 exosporium protein is composed by an N-terminal domain, possibly oriented to the inside, a collagen-like domain formed by GXX repeats, which is highly glycosylated [15], and a C-terminal domain that is presumably faced outwards of the exosporium [22]. A recent study has shown that several glycosylated peptides of the collagen-like region of BclA3 were able to induce humoral immune response in mice [24]. However, it is unclear whether the C-terminal domain of BclA3 could be used as an antigen in a $C$. difficile spore-based vaccination strategy.

In this study, the BclA3 amino acid sequence was analyzed in silico and the C-terminal domain, $\mathrm{BClA} 3_{\mathrm{CTD}}$, was identified as a potential epitope. $\mathrm{BclA} 3_{\mathrm{CTD}}$ antigenicity was then tested in vivo in a murine model as a free protein or displayed on Bacillus subtilis spores, a well-established antigen delivery system [25], proven to efficiently interact with antigen-presenting cells (APCs) leading to the induction of humoral, local and cellular responses [26,27]. Mice immunized with recombinant spores or with the pure antigen were able to produce $B \mathrm{BlA}_{\mathrm{CTD}}$-specific Immunoglobulin $\mathrm{G}$ (IgG). The immunization with pure $\mathrm{BclA} 3_{\mathrm{CTD}}$ also impaired weight loss after a challenge with $C$. difficile spores and induced a decrease in the $C$. difficile spore load in feces one day after the infection.

\section{Results}

\subsection{In Silico Analysis of Bcla3 and Construction of the Recombinant Strain Expressing the Chimera Protein $\operatorname{Cot} B \Delta-B c l A 3_{C T D}$}

To predict the most immunogenic domain of BclA3 we used the Immune Epitope Database (IEDB) to analyze BclA3 amino acid sequence and predict continuous linear B and T cell Major Histocompatibility complex (MHC)-I and MHC-II epitopes. As shown in Figure 1A, the C-terminal 170 amino acid residues of BclA3 showed the highest $\mathrm{B}$ cell antigenicity score. The prediction of $\mathrm{T}$ cell epitopes also suggests this part of the protein as the most immunogenic (Tables S1-S3). Based on that 
and on a previous report suggesting that the $\mathrm{C}$-terminus of $\mathrm{BclA} 3$ is faced outwards of the exosporium of $C$. difficile spores [22], we selected the $C$-terminal part of $B c l A 3\left(B c l A 3_{C T D}\right.$ ) (Figure $1 B$ ) as a putative antigen to be tested in vivo as a free protein and for display on the surface of $B$. subtilis spores. Hence, His-tagged BclA3 ${ }_{\text {CTD }}$ was overexpressed in Escherichia coli BL21(DE3) and purified by affinity chromatography with Ni-sepharose columns as described in the Methods section. Upon purification, the protein was loaded on a Sodium Dodecyl Sulphate-polyacrylamide gel electrophoresis (SDS-PAGE) (Figure 1C) next to pure BclA2 $\mathrm{CTD}$, an exosporium protein already purified by our group [23]. Whilst pure $\mathrm{BclA} 2_{\mathrm{CTD}}$ migrates on SDS-PAGE gel as a single band of approximately $14 \mathrm{kDa}$, as expected, pure $\mathrm{BClA}_{\mathrm{CTD}}$ consistently migrates in two bands, one with a molecular weight of about $20 \mathrm{kDa}$ and the other of about $60 \mathrm{kDa}$ that match with the predicted sizes of a monomer and a trimer, respectively, which may indicate protein aggregation.

A

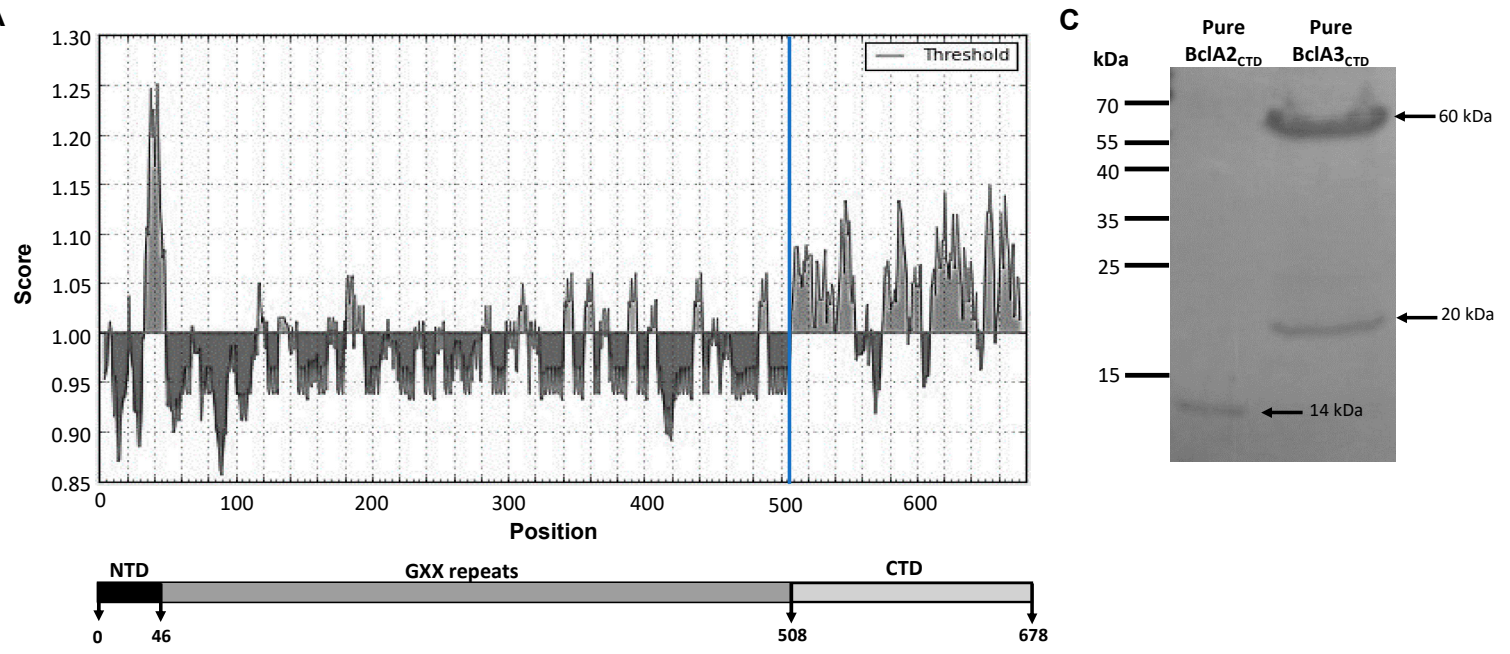

B

508 - AIIPFASGIPLSLTTIAGGLVGTPGFVGFGSSAPGLSIVGGVIDLTNAAGTLTNFAFSMP
RDGTITSISAYFSTTAALSLVGSTITITATLYQSTAPNNSFTAVPGATVTLAPPLTGILSVG
SISSGIVTGLNIAATAETRFLLVFTATASGLSLVNTVAGYASAGIAIN-678

Figure 1. Analysis of the glycoprotein BclA3 from C. difficile R20291. (A) The C-terminal domain (CTD) of BclA3 (last 170 amino acid residues) shows higher B cell epitope propensity score compared with the rest of the protein (Kolaskar \& Tongaonkar Antigenicity Method from Immune epitope database). The $\mathrm{X}$ - and Y-axes represent the sequence position and antigenic propensity score, respectively. The threshold value was generated by default by Immune epitope database (http://tools.iedb.org/bcell/). The regions above the threshold are antigenic. (B) The correspondent aminoacidic sequence of $\mathrm{BclA}_{\mathrm{CTD}}$ is shown. (C) Coomassie stained SDS-PAGE gel; 2 and $5 \mu \mathrm{g}$ of purified C-terminal domains of the exosporium proteins $\mathrm{BclA} 2$ and $\mathrm{BclA} 3$ were loaded, respectively. $\mathrm{BclA} 2_{\mathrm{CTD}}$ migrates as $14 \mathrm{kDa}$ band while $\mathrm{BclA}{ }_{\mathrm{CTD}}$ migrates as 2 bands of approximately 20 and $60 \mathrm{kDa}$.

DNA coding for the last 170 amino acid residues of $\mathrm{BclA3}$ (BclA3 $\mathrm{CTD}$ ) was used not only to over-express and purify the protein fragment but also to construct a gene fusion with DNA coding for the $B$. subtilis spore surface protein $\operatorname{CotB}$, a coat protein already used to anchor heterologous antigens in other studies [28-32]. In particular, we used a truncated version of $\operatorname{CotB}, \operatorname{Cot} B \Delta$, by deleting 105 C-terminal amino acids, thus removing a region with repeated sequences avoiding potential structural instability of the genetic constructs [28]. As previously reported [28], the gene fusion was cloned into an integrative vector adjacent to a chloramphenicol-resistant gene cassette $\left(\mathrm{Cm}^{\mathrm{R}}\right)$ and used to transform competent cells of the B. subtilis strain PY79 [33]. Chloramphenicol-resistant clones were the result of a double cross-over integration event, schematically indicated in Figure 2A. Chloramphenicol-resistant clones were tested for the site of chromosomal integration by PCR (not shown) and clone AZ703 was selected for further analysis. 
A

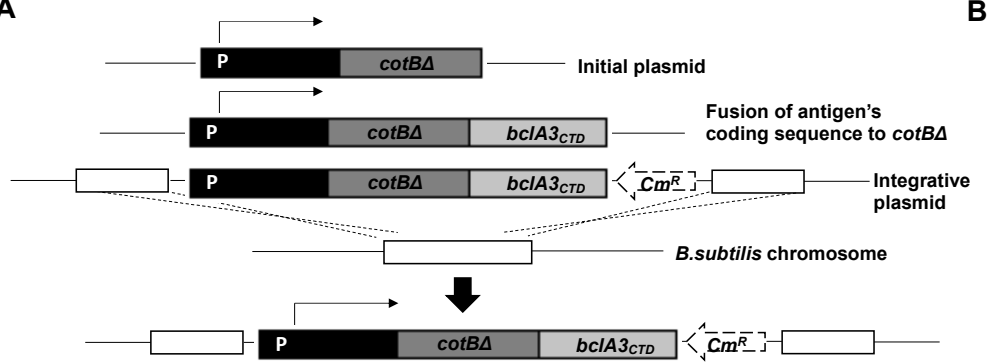

B

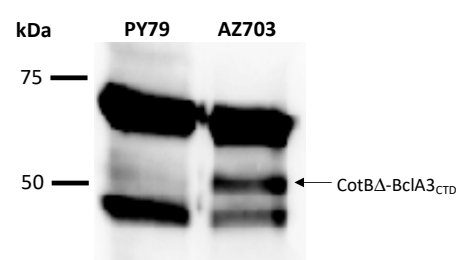

Figure 2. Construction of $B$. subtilis recombinant strain AZ703 expressing the chimera protein $\operatorname{Cot} B \Delta-B c l A 3_{C T D}$. (A) Schematic representation of the strategy for the integration of the gene fusion $\cot B \Delta:: b c l a 3_{C T D}$ in the chromosomal DNA of B. subtilis PY79. The Western blot analysis of proteins extracted from spores of $B$. subtilis laboratory strain PY79 (lane 1 in B) and from the recombinant strain AZ703 (lane 2 in B) show bands of 66 and $46 \mathrm{kDa}$, which correspond to the endogenous CotB protein. The lane of recombinant strain AZ703 also displays a band of about $50 \mathrm{kDa}$ which corresponds to the chimera protein $\operatorname{CotB} \Delta-\mathrm{BclA} 3_{\mathrm{CTD}} ; 5 \times 10^{8}$ of spores were resuspended in $100 \mu \mathrm{L}$ of loading buffer and $20 \mu \mathrm{g}$ of protein extract was loaded in SDS-PAGE gel. The immunoreaction was performed with anti-CotB antibodies and anti-rabbit secondary antibody conjugated with horseradish peroxidase.

Purified spores of strain AZ703 were used to extract surface proteins by the SDS-DTT procedure [34] and extracted proteins were analyzed by Western blot with anti-CotB antibody. CotB has a deduced molecular mass of $46 \mathrm{kDa}$ but it is known to migrate on SDS-PAGE in two forms: a predominant form of $66 \mathrm{kDa}$ and a minor form of $46 \mathrm{kDa}$ [35]. Both forms were extracted from B. subtilis laboratory strain PY79 and AZ703 spores with only the latter also showing an additional protein, slightly bigger than $50 \mathrm{kDa}$ (Figure $2 \mathrm{~B}$ ). The additional protein was recognized by the anti-CotB antibody and conformed well with the expected size for the fusion protein, since the truncated form of CotB and the BclA3 fragment have predicted sizes of $36 \mathrm{kDa}$ [23] and $20 \mathrm{kDa}$ (Figure 1C), respectively.

\subsection{Mice Intranasal Immunization}

A mucosal immunization experiment was performed in a murine model to test the efficiency of $\mathrm{BclA} 3_{\mathrm{CTD}}$ as an antigen, both as a free protein and upon display on B. subtilis spores. Mice were divided into four experimental groups and nasally immunized three times either with Phosphate buffered saline (PBS) pH $7(n=11), 2 \times 10^{9}$ spores of B. subtilis PY79 $(n=11)(\mathrm{Sp}), 2 \times 10^{9}$ spores of AZ703 $(n=11)$, or $4 \mu \mathrm{g}$ of purified $\mathrm{BclA} 3_{\mathrm{CTD}}(n=11)$. The animal serum was collected one day before the first (pre-immunization day (PI)), second (day 13) and third (day 27) immunizations as well as two days before $C$. difficile infection (day 42). One day before the infection with $5 \times 10^{7}$ spores of the $C$. difficile strain R20291, mice were treated with Clindamycin as previously reported [36] and schematically shown in Figure 3.

BclA3 $3_{\text {CTD }}$ immunogenicity was measured by ELISA analyzing the presence of anti-BclA3 $3_{C T D}$ IgG in animal serum throughout the experiment. As shown in Figure 4A mice immunized with pure $\mathrm{BclA} 3_{\mathrm{CTD}}$ produced $\mathrm{BclA} 3_{\mathrm{CTD}}$-specific IgG upon nasal administration even on the 13rd day (immunized only once). After the second and third immunizations (d27 and d41, respectively) the increase was significant ( $p<0.0001$ compared to Pre-immune serum and with d13). The recombinant spores AZ703 also induced significant levels of anti-BclA3 ${ }_{\mathrm{CTD}}$ IgG after the third immunization $(p=0.0380$ compared to Pre-immune serum). Neither PBS nor B. subtilis PY79 spores were able to raise an anti-BclA3 $3_{C T D}$ IgG response in mice, as expected. 


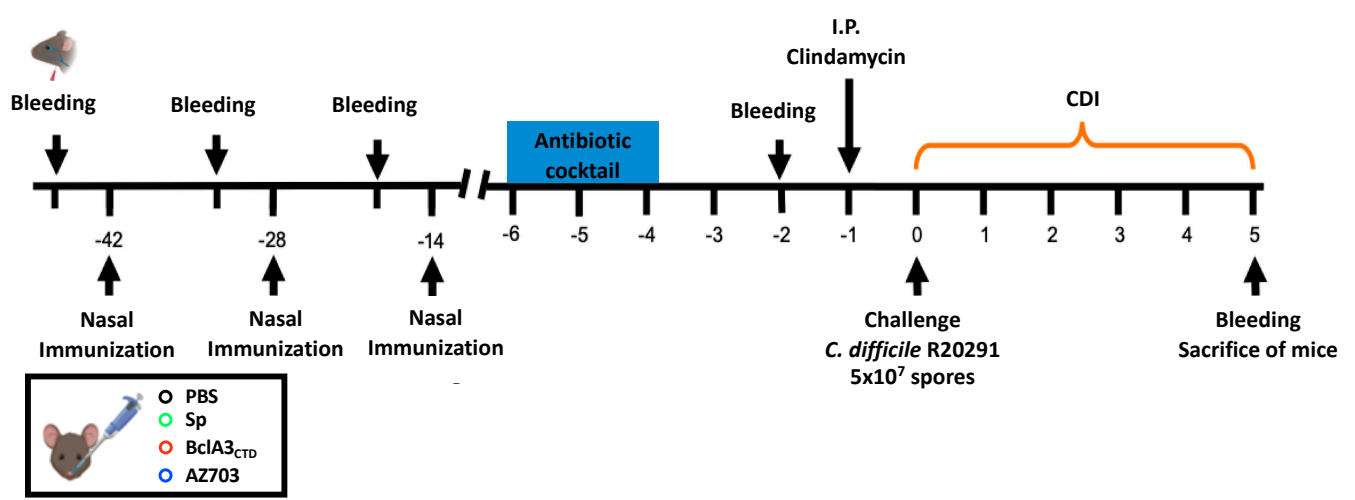

Figure 3. Schematic overview of the experimental design for the prevention of $C$. difficile infection in a murine model. C57BL/6 mice were nasally immunized three times (42, 28 and 14 days before challenge with $C$. difficile R20291 spores) with PBS, spores of B. subtilis PY79, purified BclA3 ${ }_{\text {CTD }}$ or spores of $B$. subtilis displaying the chimera protein $\operatorname{Cot} B \Delta-B c l A 3_{C T D}$ (AZ703). Prior to the infection with C. difficile R20291, the animals were submitted to an antibiotic cocktail (days 4-6 before challenge) and clindamycin administration ( 1 day before challenge). On day 0 , mice were infected with $5 \times 10^{7}$ of C. difficile R20291 spores and were monitored from day 0 to day 5 for CDI symptoms. Serum was collected one day before each immunization, two days before C. difficile infection and on the day of sacrifice.

A

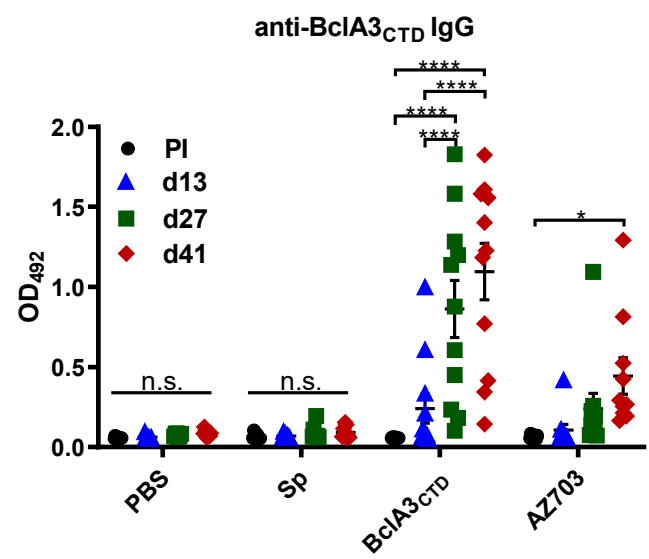

B

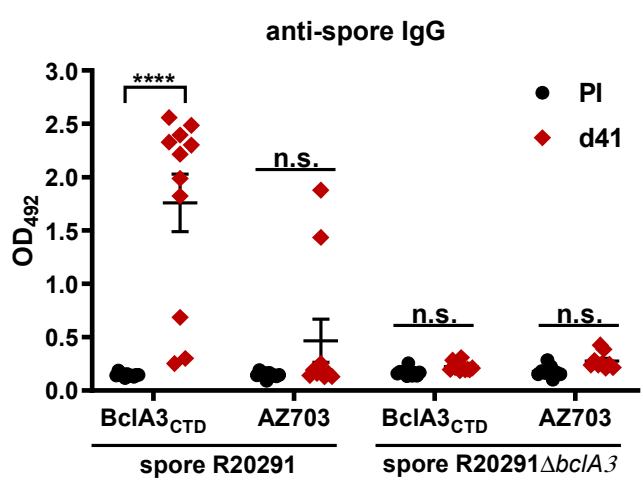

Figure 4. Evaluation of IgG anti-BclA3 $3_{\text {CTD }}$ and anti-C. difficile spores R20291 and R20291 $\Delta b c l A 3$ titers on mice serum. ELISA plates coated with $50 \mathrm{ng} /$ well of purified BclA3 ${ }_{\mathrm{CTD}}(\mathrm{A})$ or $1.6 \times 10^{7}$ spores/well of C. difficile R20291 or R20291 $\Delta$ bclA3 spores (B) were incubated with 1:100 of mice serum immunized on days 0 (Pre-Immune serum, PI), 13 (d13, before second immunization), 27 (d27, before third immunization) or day 41 (d41, before infection with $C$. difficile spores). The assessment of specific IgG anti-BclA3 $3_{\text {CTD }}$ and anti-spores was obtained using the secondary antibody 1:5000 anti-IgG mouse HRP. Results are reported as optical density (OD) units at $492 \mathrm{~nm}$. The geometric mean plus standard error of the mean for each cohort are shown. Comparisons between days in the same group were obtained using two-way ANOVA and Tukey's multiple comparison test; statistical significance $(p<0.05)$ is indicated by asterisks. ${ }^{*} p<0.05$ and ${ }^{* * * *} p<0.0001$. No significance (n.s).

The immune reactivity of the serums collected 2 days before C. difficile R20291 infection when incubated either with spores of the hyper-virulent strain R20291 or with the isogenic $b c l A 3$ mutant strain (R20291 $\Delta b c l A 3)$ was also tested. As shown in Figure 4B, mice immunized with pure BclA3 ${ }_{C T D}$ produced IgG able to recognize R20291 spores ( $p<0.0001$ in comparison to the Pre-immune serum) but not R20291 $\Delta b c l A 3$ spores indicating the specificity of the response. As expected by the low immune 
response induced by spore-displayed BclA3 (Figure 4A), only two out of eleven mice immunized with spore-displayed BclA3 ${ }_{C T D}$ produced IgG able to specifically recognize R20291.

In conclusion, results of Figure 4 show that $\mathrm{BClA}_{\mathrm{CTD}}$ is an antigen able to induce the production of BclA $3_{C T D}$-specific IgG in a murine model and serum of animals immunized with the pure antigen were also able to recognize spores of the hypervirulent strain R20291 of $C$. difficile. When displayed on $B$. subtilis spores $B c l A 3_{C T D}$ is still able to induce the production of $B c l A 3-s p e c i f i c ~ I g G$, even if at a lower level.

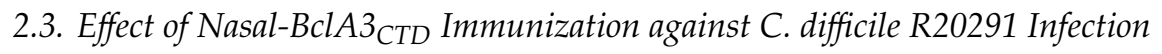

Figure $5 \mathrm{~A}$ shows that intranasal immunization with purified BclA $3_{\mathrm{CTD}}$ prevented weight loss after the challenge with $5 \times 10^{7}$ spores of the R20291 strain of C. difficile. In particular, on days 1 and 2 post-infection a statistically significant difference ( $p=0.0177$ and $p=0.0099$, respectively) was observed between mice immunized with pure BclA3 $3_{C T D}$ and those immunized with wild type spores of $B$. subtilis (Figure 5A). No statistically significant differences were observed concerning the appearance of diarrhea caused by challenge with R20291 spores, indicating that the nasal immunization with pure $B c 1 A 3_{C T D}$ or with the recombinant strain displaying $\operatorname{Cot} B \Delta-B c l A 3_{C T D}$ did not halt all CDI symptoms (Figure 5B). Plus, the severity of diarrhea, associated with a high score (zero meaning normal stool and three liquid stool), did not vary significantly between groups in the same day (Figure 5C).

A

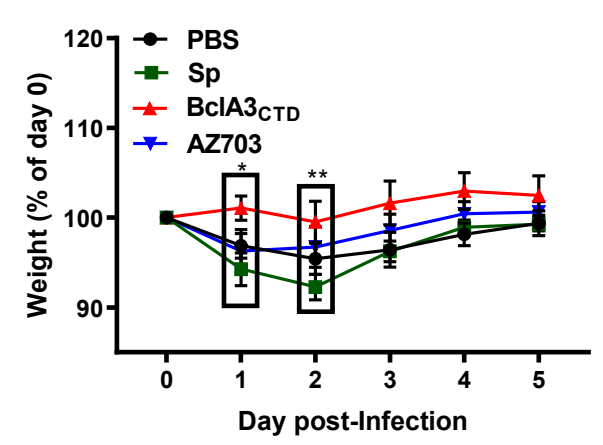

B

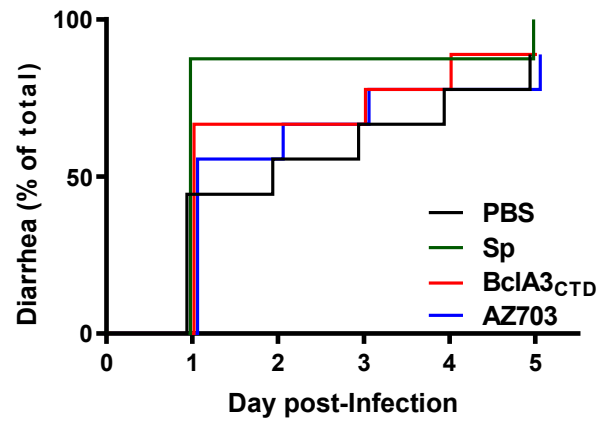

C

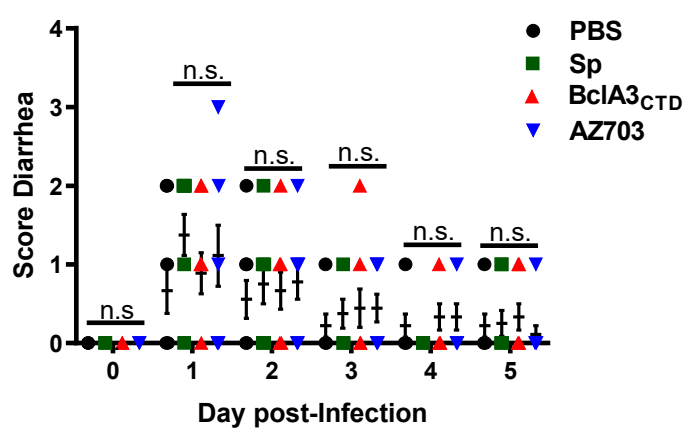

Figure 5. Protective efficacy of intranasal administration of $\mathrm{BClA}_{\mathrm{CTD}}$ and $\mathrm{AZ703}$ against $\mathrm{CDI}$ in a murine model. C57BL/6 mice were nasally immunized with PBS, B. subtilis PY79 spores, purified $\mathrm{BClA}_{\mathrm{CTD}}$ or AZ703 spores and challenged with C. difficile R20291 spores. Mice were monitored in the following 5 days after infection for (A) Weight loss presented as the relative $\%$ of the weight to the day of infection (day 0 or D0); (B) Time of occurrence of diarrhea, presented as the relative \% of diarrhea in a group to the total mice and (C) Score of diarrhea per day. Error bars are standard error of the mean. Two-way ANOVA Tukey's multiple comparisons test (A and C); Log-rank (Mantel-Cox) test (B). Statistical significance $(p<0.05)$ is indicated by asterisks. ${ }^{*} p<0.05$ and ${ }^{* *} p<0.01$. No significance (n.s). 
In order to evaluate if the immunization influenced $C$. difficile sporulation inside the host and spore clearance, we compared the spore levels present in stools within 5 days post-infection. We observed a statistically significant lower spore load in the feces of mice immunized with BclA $3_{\mathrm{CTD}}$ one day post-infection ( $p<0.0001$ with respect to mice immunized with PBS or PY79 spores and $p=0.0002$ with mice immunized with AZ703 spores) (Figure 6A) suggesting that animals immunized with the pure antigen were able to quickly eliminate $C$. difficile spores. However, from day 2 to day 5 all other groups of mice were similarly able to eliminate $C$. difficile spores (Figure 6A). No differences were observed in the $C$. difficile spore load in the ileum, proximal, middle or distal colon tissue (not shown). Finally, we measured toxin levels in mice feces, a sign of $C$. difficile colonization inside the cecum. As shown in Figure $6 \mathrm{~B}$, no statistically significant differences were observed suggesting that the immunization strategies could not prevent colonization and cytotoxicity in the cecum.

A

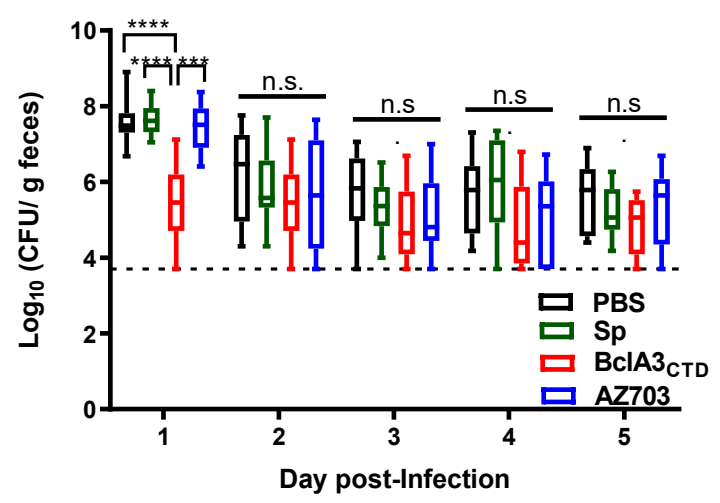

B

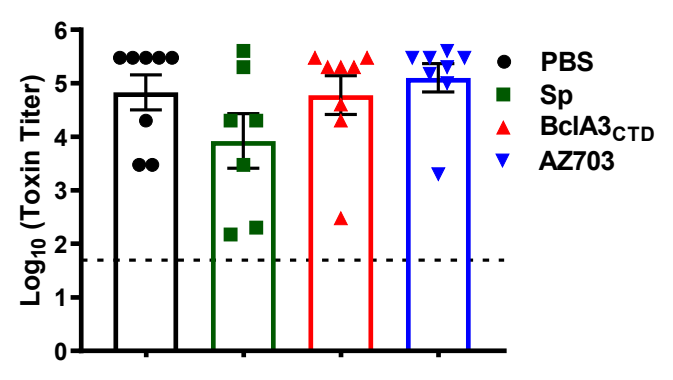

Figure 6. Analysis of spore load in feces and cecal toxin titers. (A) The load of $C$. difficile spores in the feces was evaluated on the following 5 days after infection as $\log _{10}$ Colony Forming Unit (CFU)/g of feces. (B) The cecum content toxicity was measured and represented as $\log _{10}$ toxin titer. Two-way ANOVA Tukey's multiple comparisons test in A and Mann-Whitney non-parametric tests in B were used; Statistical differences $(p<0.05)$ are indicated by asterisks. ${ }^{* * *} p<0.001$ and ${ }^{* * *} p<0.0001$. The bars are the geometric mean \pm standard error of the mean. No significance (n.s).

\section{Discussion}

Current treatment options for CDI rely on the use of antibiotics, fecal microbiota transplantation, probiotic administration or monoclonal antibodies against $C$. difficile toxins [37]. The spore, form in which $C$. difficile persists inside the host, possibly modulating its immune system, is still not considered as a main target for therapies. We have recently demonstrated that the C-terminal domain of $C$. difficile exosporium protein BclA2 elicits an elevated humoral response after nasal immunization in mice [23]. Here, we have identified as a potential antigen to induce an anti-spore immune response, the $C$-terminal domain of the exosporium protein BclA3 (BclA3 ${ }_{\mathrm{CTD}}$ ) of the hyper-virulent strain R20291 of C. difficile.

Here, we show that mice nasally immunized with pure $B c 1 A 3_{C T D}$, even only two times, were able to produce $\mathrm{BclA}_{\mathrm{CTD}}$-specific IgG (Figure $4 \mathrm{~A}$ ), indicating that the antigen was able to elicit a specific humoral immune response and therefore could be exploited for a vaccination strategy against C. difficile. Moreover, upon challenge with $C$. difficile spores, mice immunized with pure BclA $3_{C T D}$ not only maintained their weight but (Figure 5A) also had a reduction in C. difficile spore load in feces even one day after the infection (Figure 6A), improvements that so far have not been observed in mice nasally immunized with BclA2 ${ }_{\text {CTD }}$ [23]. An interesting study from Ghose et al. on 2016 using mice immunized intraperitoneally with BclA1 and challenged with spores of $C$. difficile strain UK1 have shown that despite the raise of specific IgG anti-BclA1, the immunization failed to provide protection against challenge with the pathogen [20]. In the present work, the fact that the nasally immunized animals with $\mathrm{BClA}_{\mathrm{CTD}}$ were able to show some improvements on $\mathrm{CDI}$ symptoms may suggest that this protein may be a strong candidate for vaccine strategies against CDI. Considering an induction of a robust 
specific systemic immune response, as suggested by the high titers of IgG anti- $\mathrm{BclA} 3_{\mathrm{CTD}}$, it is tempting to assume that animals immunized with the pure peptide have activated the complement signaling cascade leading to the opsonization and neutralization of $C$. difficile spores, phagocytic elimination and therefore experienced spore clearance earlier than the other groups of animals [38,39]. Effective mucosal vaccines should also induce cellular and local immune responses able to persist and sustain a protection in case of future infection with the pathogen. It is expected that exposition to $\mathrm{BclA}{ }_{\mathrm{CTD}}$ will enhance the homing of antigen-reactive lymphocytes to sites of primary immunization and $\mathrm{T}$ cell activation should prompt B cell class switching, affinity maturation, and memory establishment [40]. However, noteworthily, the immunization with pure BclA3 ${ }_{C T D}$, without adjuvant, was not able to halt neither the occurrence and intensity of diarrhea (Figure $5 B, C$ ) nor to reduce the spore load in colonic tissues (data not shown) or to avoid C. difficile spore colonization in mice cecum (Figure 6B) These results may indicate that the systemic immune response was not strong enough to prompt local immunity and a protective immune response. A change in the administration route and/or the optimization of the antigen dose could possibly overcome these limitations. The measurement of mucosal Immunoglobulin A (IgA) will be addressed in the following experiments for a better understanding of local immune response and the phenotype of the induced humoral immune response will be examined by analyzing IgG subclasses.

We have also immunized mice with $B$. subtilis spores recombinantly engineered to display $B c 1 A 3_{C T D}$ anchored to a highly abundant coat protein, CotB. Due to its safety and robustness B. subtilis spores have been widely used as mucosal vaccine vehicles [41-43]. Recombinant $B$. subtilis spores administered by the nasal route have been shown able to expose the antigen to mucosal-associated lymphoid tissue (MALT) and therefore prompt a strong immune response [44-46]. Plus, it is shown that antigens are more protected from enzymatic lysis and have increased stability when displayed into B. subtilis spore surface than free antigen [26,47]. Nevertheless, our work only showed a slight increase in specific anti-BclA3 ${ }_{\text {CTD }} \operatorname{IgG}$ in mice immunized with recombinant spores and only after three shots of immunizations (Figure 4A). Consequently, it is not surprising that we have not observed and impairment in CDI symptoms (Figures 5 and 6). These results contrast with our previous study, where we observed that immunizing mice through nasal delivery with B. subtilis spores adsorbed with BclA2 $2_{C T D}$ on the spore surface yielded similar titers as with pure BclA2 $2_{C T D}$ [23]. This could explain, in part, the low titers against BclA3 $3_{C T D}$ observed by the ELISA using sera from mice that were immunized with $B$. subtilis spores expressing chimera $\operatorname{Cot} B \Delta-B c 1 A 3_{C T D}$ protein. Although, immunoblot analysis (Figure $2 \mathrm{~B}$ ) indicates that the chimeric protein $\operatorname{Cot} B \Delta-B c l A 3_{C T D}$ is expressed and present as a fusion in the spore coat of $B$. subtilis spores, it is unclear whether the fusion expressed in the spore coat is displayed on the spore surface and accessible to antibodies or buried in the spore coat layer. At this time, we are unable to assess the amount of surface displayed CotB $\Delta-B c l A 3_{C T D}$ and surface accessibility to antibodies by fluorescence-activated cell sorting (FACS) or quantitative Western. We acknowledge this limitation and will assess quantitative surface display of chimeric $\operatorname{CotB} \Delta-\mathrm{Bcl} A 3_{\mathrm{CTD}}$ protein in further studies seeking to optimize $B$. subtilis recombinant surface display and/or adsorption of $C$. difficile exosporium proteins. In this context, it is known that recombinant spores of $B$. subtilis administered by gavage germinate in the stomach and small intestine and due to low oxygen present in the large bowel environment they re-sporulate displaying the heterologous antigen again [48-50] therefore, the oral delivery of recombinant $B$. subtilis spores would be also considered and interesting option since it allows higher doses and number of immunizations. Additionally, the use of adjuvants with immunostimulatory capacities, such as Toll-Like Receptors (TLR) and NOD-Like Receptor (NLR) ligands [51] or probiotics [52] might boost the expected immune response. A recent study has shown that humoral and cellular immune responses observed in mice nasally immunized with $B$. subtilis spores displaying the $C$ fragment of the tetanus toxin (TTFC) on the surface were enhanced in mice previously submitted to Bacillus toyonencis as probiotic [52]. Therefore, the use of these kinds of strategies would contribute to an improvement in this work. 
In conclusion, the induction of humoral immune response and the partial protective effects observed in animals nasally immunized with the purified protein $B c 1 A 3_{C T D}$ clearly indicate that $\mathrm{BClA}_{\mathrm{CTD}}$ is a promising antigen to be tested in future in vivo trials.

\section{Materials and Methods}

\subsection{Bacterial Strains and Spore Purification}

E. coli strains DH5 $\alpha$ and BL21 (DE3) (Invitrogen, Agawam, MA, USA) were used for cloning and BclA3 ${ }_{\text {CTD }}$ overexpression, respectively. B. subtilis PY79 [33] was used as a a parental strain of AZ703. The hyper-virulent strain R20291 of C. difficile was used for mice infection. To test BclA3 ${ }_{C T D}$-specific immunogenicity an R20291 $\Delta b c l A 3$ knockout mutant was used (Paredes-Sabja, unpublished work).

Sporulation of B. subtilis PY79 and AZ703 was induced by the exhaustion method [53]. Briefly, after $35 \mathrm{~h}$ of growth in Difco Sporulation (DS) medium at $37{ }^{\circ} \mathrm{C}$ with vigorous shaking, spores were collected, washed and purified. The purification was performed using $\mathrm{KCl} 1 \mathrm{M}$, lysozyme $10 \mathrm{mM}, \mathrm{NaCl} 1 \mathrm{M}$, SDS $0.05 \%$ and several washes with water.

C. difficile spores were purified as described elsewhere [54]. Spore suspensions were prepared by plating a 1:100 dilution of an overnight culture onto a 70:30 medium (63 g Bacto peptone (ThermoFisher, Agawam, MA, USA), $3.5 \mathrm{~g}$ proteose peptone (ThermoFisher), $0.7 \mathrm{~g}$ ammonium sulfate $\left(\mathrm{NH}_{4}\right)_{2} \mathrm{SO}_{4}, 1.06 \mathrm{~g}$ Tris base, $11.1 \mathrm{~g}$ brain heart infusion extract (ThermoFisher) and $1.5 \mathrm{~g}$ yeast extract (ThermoFisher) for $1 \mathrm{~L}$ ) and incubating it for 5 days at $37^{\circ} \mathrm{C}$ under anaerobic conditions [55]. After incubation, plates were removed from the chamber and the surface was scraped up with ice-cold sterile water. Next, the spores were washed five times gently with ice-cold sterile water in micro centrifuge at 14,000 rpm for $5 \mathrm{~min}$. Spores were loaded onto a $45 \%$ Nycodenz solution, centrifuged (14,000 rpm, $40 \mathrm{~min})$. After centrifugation, the spore pellet was washed five times (14,000 rpm, $5 \mathrm{~min})$ with ice-cold sterile water to remove Nycodenz remnants.

The spores were counted in Neubauer chamber and volume adjust at $5 \times 10^{9}$ spores per $\mathrm{mL}$. Spore suspensions were purified until they were $>99 \%$ free of vegetative cells, sporulating cells and cell debris as determined by phase-contrast microscopy.

\subsection{BclA3 ${ }_{C T D}$ Over-Production and Purification}

The chromosomal DNA of $C$. difficile R20291 was used for the amplification of bcla3 C-terminal domain (CTD) $(513 \mathrm{bp})$ with the oligonucleotides BclA3 ${ }_{\text {CTDsense }}$ (ggtaccggatccGCAATAATACCTTTTGCATCAGG, in lower case is the recognition site for KpnI, NcoI and BamHI restriction enzymes) and BclA3 $3_{C T D a n t i}$ (tctagactgcagCTAATTTATTGCAATTCCTGCAC in lower case is the recognition site for $\mathrm{XbaI}$ and PstI restriction enzymes) to prime the reaction. The coding sequence of BclA3 $3_{C T D}$ was cloned in the plasmid pGEMT-easy (Promega) and posteriorly cleaved with BamHI/PstI restriction enzymes and inserted in-frame to an N-terminal polyhistidine tag in the expression vector pRSETA (Invitrogen), previously digested with the same enzymes. Upon transformation of E. coli BL21(DE3) with pRSETA::bcla3 $3_{C T D}$, the strain was incubated in ampicillin-supplemented $(50 \mu \mathrm{g} / \mathrm{mL}) \mathrm{TY}$ medium. Once reached an optical density of 0.7 at $600 \mathrm{~nm}$ the culture was added to an autoinduction medium (T7 promoter induction by lactose) and incubated for $16 \mathrm{~h}$ at $37{ }^{\circ} \mathrm{C}$ with shaking. The six-His-tagged BclA $3_{\mathrm{CTD}}$ protein was purified under native conditions using the His-Trap column as recommended by the manufacturer (GE Healthcare Life Science, Darmstardt, Germany). The purified protein was desalted and concentrated with the Centricon cutoff $10 \mathrm{kDa}$ (Merck Millipore, Darmstardt, Germany). The purity of the protein was analyzed by SDS-PAGE and Western blot using Anti-His antibodies. 


\subsection{Construction of the Recombinant Strain AZ703}

DNA coding for BclA3 $3_{C T D}$ and for the N-terminal 275 amino acids of CotB were PCR amplified using the C. difficile R20291 and B. subtilis PY79 chromosome as template, respectively. To prime cotBA the oligonucleotides B1 (acatgcatgcACGGATTAGGCCGTTTGTCC in lower case there is the recognition site for SphI restriction enzyme) and B3 (gaaagatctGGATGATTGATCATCTGAAG in lower case there is the recognition site for BglII restriction enzyme) were used. The obtained amplification products were cloned in pGEMT-easy (yielding pGEMT-easy::bclA3 $3_{C T D}$ and pGEMT-easy:: $\cot B \Delta$ ). The $b c l A 3_{C T D}$ gene was digested from pGEMT-easy::bclA3 $3_{C T D}$ with BamHI/PstI restriction enzymes and cloned in-frame to the $3^{\prime}$ end of the $\cot B \Delta$ gene carried by plasmid pGEMT-easy:: $\cot B \Delta$ previously diggested with BglII/PstI, yielding plasmid pGEMT-easy:: $\cot B \triangle:: b c l A 3_{C T D}$. The fusion $\cot B \triangle:: b c l A 3_{C T D}$ gene was digested with the restriction enzymes SphI/SalI and ligated to the previously digested integrative plasmid pDG364 which contains a coding region for chloramphenicol resistance. Competent B. subtilis PY79 cells were transformed with the previously linearized integrative vector with NdeI and plated in medium with chloramphenicol. The antibiotic-resistant clones were the result of double-crossover recombination with amyE gene on the B. subtilis chromosome. The chromosomal DNA was extracted from the positive clones and tested by PCR. Sporulation of PY79 and recombinant strain (AZ703) was induced by nutrient exhaustion in DS medium. After $35 \mathrm{~h}$ incubation at $37^{\circ} \mathrm{C}$, spores were collected, washed and purified as described before. The coat proteins from $5 \times 10^{8}$ spores of PY79 and AZ703 were extracted by SDS-DTT treatment. To verify the expression of the chimera protein $\operatorname{Cot} B-B C l A 3_{C T D}$, extracted proteins were analyzed by Western blot using anti-CotB antibodies.

\subsection{Western Blot Analysis}

The coat proteins from $5 \times 10^{8}$ spores of B. subtilis PY79 and AZ703 were extracted by SDS-DTT treatment [34] and quantified by Bradford assay (BioRad, Milan, Italy). In total, $20 \mu \mathrm{g}$ of protein extract, $5 \mu \mathrm{g}$ and $2 \mu \mathrm{g}$ of pure $\mathrm{BclA}{ }_{\mathrm{CTD}}$ and $\mathrm{BclA}{ }_{\mathrm{CTD}}$, respectively, were treated with protein sample buffer $2 \times$ [56], incubated at $100{ }^{\circ} \mathrm{C}$ for $7 \mathrm{~min}$ and loaded onto a $12 \%$ or $15 \%$ SDS-PAGE gel. Proteins were then electro-transferred to nitrocellulose filters (Amersham Pharmacia Biotech, Milan, Italy) and used for Western blot analysis by standard procedures. To identify the recombinant protein $\operatorname{Cot} B \Delta-B c l A 3_{C T D}$ it was used anti-CotB 1:7000 as primary antibody and anti-rabbit secondary antibody conjugated with horseradish peroxidase 1:7000. To identify pure BclA3 ${ }_{\text {CTD }}$ it was used the antibody anti-His 1:7000.

\subsection{Animals}

Mice 8-12 weeks old C57BL/6 (male or female) were obtained from a breeding colony at Facultad de Ciencias Biologicas, Universidad Andres Bello (Santiago, Chile), established using animals purchased from Jackson Laboratories (Protocol number 0035/2018, project identification code: Fondef ID18/10230; approval date: 22 January 2018; approval act code 0035/2018; approval committee: Comité de Bioética de la Faculdad de Ciencias Biologicas). Water, bedding and cages were previously autoclaved, and mice had a 12-h cycle of light and darkness. All experimental protocols were conducted in strict accordance with and under the formal approval of the Biologicals Sciences Faculty of Universidad Andrés Bello.

\subsection{Immunization Regimen in Mice}

Mice were randomly assigned to four experimental groups (11 animals each group) according to the type of immunization received. Mice were intranasally immunized on days 0,14 and 28 with $20 \mu \mathrm{L}\left(10 \mu \mathrm{L}\right.$ per nostril) of PBS pH 7, $2 \times 10^{9}$ spores of B. subtilis PY79, $2 \times 10^{9}$ spores of AZ703 or $4 \mu \mathrm{g}$ of purified $\mathrm{BclA} 3_{\mathrm{CTD}}$. The day before each immunization, two days before infection and on the day of the sacrifice blood was collected. 


\subsection{Animal Infection Model}

Prior to infection, mice were pre-treated with an antibiotic cocktail of kanamycin ( $40 \mathrm{mg} / \mathrm{kg}$ body weight; Sigma-Aldrich, St. Louis, MO, USA), gentamicin ( $3.5 \mathrm{mg} / \mathrm{kg}$ body weight; Sigma-Aldrich), colistin $(4.2 \mathrm{mg} / \mathrm{kg}$ body weight; Sigma-Aldrich), metronidazole $(21.5 \mathrm{mg} / \mathrm{kg}$ body weight; Sigma-Aldrich) and vancomycin (40 mg/kg body weight; Sigma-Aldrich) for 3 days by oral administration [36]. Two days after the antibiotic treatment, mice were intraperitoneally administrated with a single dose of clindamycin $(10 \mathrm{mg} / \mathrm{kg})$ and on the next day were infected orogastrically with $100 \mu \mathrm{L}$ of PBS containing $5 \times 10^{7}$ spores of $C$. difficile strain R20291. Mice were housed individually in sterile cages with ad libitum access to food and water. All procedures and mouse handling were performed aseptically in a biosafety cabinet to contain spore-mediated transmission.

The clinical condition of mice was monitored daily with a scoring system. The presence of diarrhea was classified according to severity as follows: (i) normal stool (score $=0$ ); (ii) color change/consistency (score $=1$ ); (iii) presence of wet tail or mucosa (score $=2$ ); (iv) liquid stools (score $=3$ ). A score higher than 1 was considered as diarrhea [57]. The animals were weighted daily after infection and other clinical symptoms as physical aspect (i.e., abnormal/hunched gait, piloerection), spontaneous behavior (i.e., lethargy, inactivity or lack of mobility) and emaciation were monitored as described [58]. Moribund mice or mice displaying overt signs of disease were sacrificed. At the time of sacrifice, ileum, proximal, median and distal colon were collected as well as the cecal content.

\subsection{Evaluation of $B c l A 3_{C T D}$-Specific IgG Levels in Mice Serum}

The blood collected the day before each immunization, two days before infection and at the time of sacrifice was incubated at $37^{\circ} \mathrm{C}$ for $30 \mathrm{~min}$ and then centrifuged at $5000 \mathrm{rpm}$ for $10 \mathrm{~min}$ at $4{ }^{\circ} \mathrm{C}$. The supernatant, containing the serum fraction was stored at $-20{ }^{\circ} \mathrm{C}$ until use. To assess the production of IgG against $\mathrm{BclA} 3_{\mathrm{CTD}}$, an Enzyme-linked immunosorbent assay (ELISA) was performed. Purified $\mathrm{BclA}_{\mathrm{CTD}}\left(50 \mathrm{ng} /\right.$ well), spores of $C$. difficile R20291 $\left(1.6 \times 10^{7}\right.$ spores/well) or C. difficile R20291 $\Delta b$ cla3 $\left(1.6 \times 10^{7}\right.$ spores/well) were coated onto 96-wells plates and incubated overnight at $4{ }^{\circ} \mathrm{C}$. Then, the samples were blocked with PBS- $0.05 \%$ Tween-20 (PBS-T) containing $2 \%$ BSA for $1 \mathrm{~h}$ at $37^{\circ} \mathrm{C}$. After several washes, the wells were next incubated with 1:100 of animal serum (in 1\% BSA in PBS-T). The plates were incubated $2 \mathrm{~h}$ at $37^{\circ} \mathrm{C}$. After the removal of non-adherent IgG by several washes, the plates were incubated with 1:5000 secondary antibody anti-IgG mouse HRP, for $1 \mathrm{~h}$ at $37^{\circ} \mathrm{C}$. Finally, the colorimetric reaction was initiated upon the addition of $50 \mu \mathrm{L}$ of reaction buffer containing $0.05 \mathrm{M}$ citric acid, $0.1 \mathrm{M}$ disodiumhydrogen phosphate, $2 \mathrm{mg} / \mathrm{mL}$ of o-phenlyendiamine (Sigma-Aldrich, USA) and $0.015 \%$ of $\mathrm{H}_{2} \mathrm{O}_{2}$ (Merck, Darmstadt, Germany). The reaction was stopped after 20 min with $25 \mu \mathrm{L}$ of $4.5 \mathrm{~N}$ of $\mathrm{H}_{2} \mathrm{SO}_{4}$ and absorbance was measured at $492 \mathrm{~nm}$. The experiment was performed in duplicate.

\subsection{Quantification of C. difficile Spores from Feces and Colon Samples}

Fecal samples were collected in the following five days after infection and were stored at $-20{ }^{\circ} \mathrm{C}$ until $\mathrm{C}$. difficile spore quantification. On the day of the analysis, $10 \mu \mathrm{L}$ of PBS was added for each mg of stools, mixed and incubated for $30 \mathrm{~min}$ at room temperature. Then, $50 \mu \mathrm{L}$ of absolute ethanol (Sigma-Aldrich) was added to $50 \mu \mathrm{L}$ of feces and incubated for $30 \mathrm{~min}$ at room temperature. Samples were serially diluted and plated onto selective media supplemented with Taurocholate $(0.1 \% w / v)$, Cefoxitin $(16 \mu \mathrm{g} / \mathrm{mL})$ and L-cycloserine $(250 \mu \mathrm{g} / \mathrm{mL})$ (TCCFA plates). The plates were incubated anaerobically at $37^{\circ} \mathrm{C}$ for $48 \mathrm{~h}$, the $\mathrm{C}$. difficile colonies were counted, and the results were expressed as the $\log _{10}$ of $\mathrm{CFU} / \mathrm{g}$ of feces.

Proximal, median and distal colons were collected from mice upon sacrifice and washed with PBS with a syringe. They were posteriorly resuspended and homogenized with $2.5 \mu \mathrm{L}$ of PBS for each mg of tissue. Upon incubation at room temperature with absolute ethanol and serial dilution, they were 
plated onto TCCFA plates. The plates were incubated anaerobically at $37^{\circ} \mathrm{C}$ for $48 \mathrm{~h}$. Finally, the colony count was expressed as the $\log _{10}$ of $\mathrm{CFU} / \mathrm{g}$ of tissue.

\subsection{Cytotoxicity Assay}

Vero cell cytotoxicity was performed as described previously [59]. Briefly, 96-well flat-bottom microtiter plates were seeded with Vero cells at a density of $10^{5}$ cells/well. Mice cecal contents were kept at $-20{ }^{\circ} \mathrm{C}$ prior use. At the time of the experiment cecal contents were suspended in PBS (10 $\mu \mathrm{L}$ of PBS per $\mathrm{mg}$ of cecal content), vortexed and centrifuged $(14,000 \mathrm{rpm}, 5 \mathrm{~min})$. The filter-sterilized supernatant was serially diluted in Dulbecco's Modified Eagle Medium (DMEM) supplemented with $10 \%$ fetal bovine serum (FBS) and 1\% penicillin-streptomycin. In total, $100 \mu \mathrm{L}$ of each dilution was added to wells containing Vero cells. Plates were screened for cell rounding $16 \mathrm{~h}$ after incubation at $37{ }^{\circ} \mathrm{C}$. The cytotoxic titer was defined as the reciprocal of the highest dilution that produced rounding in at least $80 \%$ of Vero cells per gram of luminal samples under $\times 200$ magnification.

\subsection{Statistical Analysis}

Prism 8 (GraphPad Software, Inc.) was used for statistical analysis. Normality was assessed by Shapiro-Wilk test. For populations that did not follow a normal distribution significance between groups was assessed by a Mann-Whitney unpaired $t$-test. Comparative analysis between groups was performed by analysis of variance with Tukey's multiple comparison test for populations that followed a normal distribution. A $p$-value of $\leq 0.05$ was accepted as the level of statistical significance.

Supplementary Materials: Supplementary materials can be found at http://www.mdpi.com/1422-0067/21/18/ 6696/s1.

Author Contributions: Conceptualization, A.R.M., E.R., L.B. and D.P.-S.; methodology, A.R.M., R.R.-R., M.P.-G. and A.S.; validation, A.R.M., A.S., E.R., L.B. and D.P.-S.; formal analysis, A.R.M., R.R.-R., M.P.-G.; investigation, A.R.M., R.R.-R., M.P.-G.; resources, E.R., L.B. and D.P.-S.; data curation, A.R.M., R.R.-R., M.P.-G.; writing-original draft preparation, A.R.M. and D.P.-S.; writing-review and editing, E.R., L.B. and D.P.-S.; visualization, A.R.M., R.R.-R., M.P.-G., A.S., E.R., L.B. and D.P.-S.; supervision, E.R., L.B. and D.P.-S.; project administration, L.B. and D.P.-S.; funding acquisition, L.B. and D.P.-S. All authors have read and agreed to the published version of the manuscript.

Funding: This research was funded by: "Finanziamento di Ricerca di Ateneo" to L.B, project title "SP-LAY: Bacterial spores as live platform for proteins display"; Fondo Nacional de Ciencia y Tecnología de Chile (FONDECYT Grant 1151025, 1191601); Millennium Science Initiative of the Ministry of Economy, Development and Tourism to D.P-S. Support was also provided by a grant from Fondo de Fomento al Desarrollo Científico y Tecnológico (FONDEF) ID18|10230 to M.P.-G and D.P.-S.

Conflicts of Interest: The authors declare no conflicts of interest.

\section{Abbreviations}

$\begin{array}{ll}\text { CDI } & \text { Clostridioides difficile infection } \\ \text { IECs } & \text { Intestinal epithelial cells } \\ \text { BclA } & \text { Bacillus collagen-like protein of anthracis } \\ \text { NTD } & \text { N-terminal domain } \\ \text { CTD } & \text { C-terminal domain } \\ \text { BclA2 } 2 \text { CD } & \text { C-terminal domain of BclA2 } \\ \text { BclA3 } 3 \text { TD } & \text { C-terminal domain of BclA3 } \\ \text { APCs } & \text { Antigen-presenting cells } \\ \text { IEDB } & \text { Immune epitope database } \\ \text { MHC } & \text { Major Histocompatibility complex } \\ \text { SDS-PAGE } & \text { Sodium Dodecyl Sulphate-polyacrylamide gel electrophoresis } \\ \text { Sp } & \text { Spores of B. subtilis } \\ \text { PBS } & \text { Phosphate buffered saline }\end{array}$




$\begin{array}{ll}\text { ANOVA } & \text { Analysis of variance } \\ \text { ELISA } & \text { Enzyme-linked immunosorbent assay } \\ \text { IgG } & \text { Immunoglobulin G } \\ \text { IgA } & \text { Immunoglobulin A } \\ \text { MALT } & \text { Mucosal-associated lymphoid tissue } \\ \text { I.P } & \text { Intraperitoneal } \\ \text { Wt } & \text { Wild type } \\ \text { PI } & \text { Pre-Immune } \\ \text { d13 } & \text { Day 13 } \\ \text { d27 } & \text { Day 27 } \\ \text { d42 } & \text { Day } 42 \\ \text { OD } & \text { Optical density } \\ \text { CFU } & \text { Colony forming unit } \\ \text { TTFC } & \text { C fragment of the tetanus toxin } \\ \text { TLR } & \text { Toll-Like Receptors } \\ \text { NLR } & \text { Nod-Like Receptors } \\ \text { FACS } & \text { Fluorescence-activated cell sorting } \\ \text { DMEM } & \text { Dulbecco's Modified Eagle Medium }\end{array}$

\section{References}

1. Kelly, C.P.; Pothoulakis, C.; LaMont, J.T. Clostridium difficile colitis. N. Engl. J. Med. 1994, 330, $257-262$. [CrossRef] [PubMed]

2. Centers for Disease Control and Prevention. Antibiotic resistance threats in the United States, 2019. Available online: https://www.cdc.gov/drugresistance/pdf/threats-report/2019-ar-threats-report-508.pdf (accessed on 30 June 2020).

3. Oh, S.H.; Kang, H.Y. Identification of target risk groups for population-based Clostridium difficile infection prevention strategies using a population attributable risk approach. Int. J. Infect. Dis. 2018, 66, 107-112. [CrossRef] [PubMed]

4. Johnson, S.; Adelmann, A.; Clabots, C.R.; Peterson, L.R.; Gerding, D.N. Recurrences of Clostridium difficile diarrhea not caused by the original infecting organism. J. Infect. Dis. 1989, 159, 340-343. [CrossRef]

5. O'Neill, G.L.; Beaman, M.H.; Riley, T.V. Relapse versus reinfection with Clostridium difficile. Epidemiol. Infect. 1991, 107, 627-635. [CrossRef] [PubMed]

6. Wilcox, M.H.; Fawley, W.N.; Settle, C.D.; Davidson, A. Recurrence of symptoms in Clostridium difficile infection-relapse or reinfection? J. Hosp. Infect. 1998, 38, 93-100. [CrossRef]

7. Miller, B.A.; Chen, L.F.; Sexton, D.J.; Anderson, D.J. Comparison of the burdens of hospital-onset, healthcare facility-associated Clostridium difficile Infection and of healthcare-associated infection due to methicillin-resistant Staphylococcus aureus in community hospitals. Infect. Control Hosp. Epidemiol. 2011, 32, 387-390. [CrossRef]

8. Wiegand, P.N.; Nathwani, D.; Wilcox, M.H.; Stephens, J.; Shelbaya, A.; Haider, S. Clinical and economic burden of Clostridium difficile infection in Europe: A systematic review of healthcare-facility-acquired infection. J. Hosp. Infect. 2012, 81, 1-14. [CrossRef]

9. Zhang, S.; Palazuelos-Munoz, S.; Balsells, E.M.; Nair, H.; Chit, A.; Kyaw, M.H. Cost of hospital management of Clostridium difficile infection in United States-a meta-analysis and modelling study. BMC Infect. Dis. 2016, 16, 447. [CrossRef]

10. Sarker, M.R.; Paredes-Sabja, D. Molecular basis of early stages of Clostridium difficile infection: Germination and colonization. Future Microbiol. 2012, 7, 933-943. [CrossRef]

11. Heinlen, L.; Ballard, J.D. Clostridium difficile infection. Am. J. Med. Sci. 2010, 340, 247-252. [CrossRef]

12. Barra-Carrasco, J.; Paredes-Sabja, D. Clostridium difficile spores: A major threat to the hospital environment. Future Microbiol. 2014, 9, 475-486. [CrossRef] [PubMed]

13. Escobar-Cortes, K.; Barra-Carrasco, J.; Paredes-Sabja, D. Proteases and sonication specifically remove the exosporium layer of spores of Clostridium difficile strain 630. J. Microbiol. Methods 2013, 93, 25-31. [CrossRef]

14. Joshi, L.T.; Phillips, D.S.; Williams, C.F.; Alyousef, A.; Baillie, L. Contribution of spores to the ability of Clostridium difficile to adhere to surfaces. Appl. Environ. Microbiol. 2012, 78, 7671-7679. [CrossRef] [PubMed] 
15. Strong, P.C.; Fulton, K.M.; Aubry, A.; Foote, S.; Twine, S.M.; Logan, S.M. Identification and characterization of glycoproteins on the spore surface of Clostridium difficile. J. Bacteriol. 2014, 196, 2627-2637. [CrossRef] [PubMed]

16. Xue, Q.; Gu, C.; Rivera, J.; Hook, M.; Chen, X.; Pozzi, A.; Xu, Y. Entry of Bacillus anthracis spores into epithelial cells is mediated by the spore surface protein $\mathrm{BclA}$, integrin alpha2beta1 and complement component $\mathrm{C} 1 \mathrm{q}$. Cell Microbiol. 2011, 13, 620-634. [CrossRef]

17. Barra-Carrasco, J.; Olguin-Araneda, V.; Plaza-Garrido, A.; Miranda-Cardenas, C.; Cofre-Araneda, G.; Pizarro-Guajardo, M.; Sarker, M.R.; Paredes-Sabja, D. The Clostridium difficile exosporium cysteine (CdeC)-rich protein is required for exosporium morphogenesis and coat assembly. J. Bacteriol. 2013, 195, 3863-3875. [CrossRef] [PubMed]

18. Pizarro-Guajardo, M.; Calderon-Romero, P.; Castro-Cordova, P.; Mora-Uribe, P.; Paredes-Sabja, D. Ultrastructural Variability of the Exosporium Layer of Clostridium difficile Spores. Appl. Environ. Microbiol. 2016, 82, 2202-2209. [CrossRef] [PubMed]

19. Mora-Uribe, P.; Miranda-Cardenas, C.; Castro-Cordova, P.; Gil, F.; Calderon, I.; Fuentes, J.A.; Rodas, P.I.; Banawas, S.; Sarker, M.R.; Paredes-Sabja, D. Characterization of the Adherence of Clostridium difficile Spores: The Integrity of the Outermost Layer Affects Adherence Properties of Spores of the Epidemic Strain R20291 to Components of the Intestinal Mucosa. Front. Cell Infect. Microbiol. 2016, 6, 99. [CrossRef]

20. Ghose, C.; Eugenis, I.; Edwards, A.N.; Sun, X.; McBride, S.M.; Ho, D.D. Immunogenicity and protective efficacy of Clostridium difficile spore proteins. Anaerobe 2016, 37, 85-95. [CrossRef]

21. Phetcharaburanin, J.; Hong, H.A.; Colenutt, C.; Bianconi, I.; Sempere, L.; Permpoonpattana, P.; Smith, K.; Dembek, M.; Tan, S.; Brisson, M.C.; et al. The spore-associated protein BclA1 affects the susceptibility of animals to colonization and infection by Clostridium difficile. Mol. Microbiol. 2014, 92, 1025-1038. [CrossRef] [PubMed]

22. Pizarro-Guajardo, M.; Olguin-Araneda, V.; Barra-Carrasco, J.; Brito-Silva, C.; Sarker, M.R.; Paredes-Sabja, D. Characterization of the collagen-like exosporium protein, BclA1, of Clostridium difficile spores. Anaerobe 2014, 25, 18-30. [CrossRef] [PubMed]

23. Maia, A.R.; Reyes-Ramirez, R.; Pizarro-Guajardo, M.; Saggese, A.; Castro-Cordova, P.; Isticato, R.; Ricca, E.; Paredes-Sabja, D.; Baccigalupi, L. Induction of a Specific Humoral Immune Response by Nasal Delivery of Bcla2ctd of Clostridioides difficile. Int. J. Mol. Sci. 2020, 21, 1277. [CrossRef] [PubMed]

24. Aubry, A.; Zou, W.; Vinogradov, E.; Williams, D.; Chen, W.; Harris, G.; Zhou, H.; Schur, M.J.; Gilbert, M.; Douce, G.R.; et al. In vitro Production and Immunogenicity of a Clostridium difficile Spore-Specific BclA3 Glycopeptide Conjugate Vaccine. Vaccines 2020, 8, 73. [CrossRef] [PubMed]

25. Cutting, S.M.; Hong, H.A.; Baccigalupi, L.; Ricca, E. Oral vaccine delivery by recombinant spore probiotics. Int. Rev. Immunol. 2009, 28, 487-505. [CrossRef]

26. Huang, J.M.; Hong, H.A.; Van Tong, H.; Hoang, T.H.; Brisson, A.; Cutting, S.M. Mucosal delivery of antigens using adsorption to bacterial spores. Vaccine 2010, 28, 1021-1030. [CrossRef] [PubMed]

27. de Souza, R.D.; Batista, M.T.; Luiz, W.B.; Cavalcante, R.C.; Amorim, J.H.; Bizerra, R.S.; Martins, E.G.; Ferreira, L.C. Bacillus subtilis spores as vaccine adjuvants: Further insights into the mechanisms of action. PLoS ONE 2014, 9, e87454. [CrossRef]

28. Isticato, R.; Cangiano, G.; Tran, H.T.; Ciabattini, A.; Medaglini, D.; Oggioni, M.R.; De Felice, M.; Pozzi, G.; Ricca, E. Surface display of recombinant proteins on Bacillus subtilis spores. J. Bacteriol. 2001, 183, 6294-6301. [CrossRef] [PubMed]

29. Hoang, T.H.; Hong, H.A.; Clark, G.C.; Titball, R.W.; Cutting, S.M. Recombinant Bacillus subtilis expressing the Clostridium perfringens alpha toxoid is a candidate orally delivered vaccine against necrotic enteritis. Infect. Immun. 2008, 76, 5257-5265. [CrossRef] [PubMed]

30. Hinc, K.; Isticato, R.; Dembek, M.; Karczewska, J.; Iwanicki, A.; Peszynska-Sularz, G.; De Felice, M.; Obuchowski, M.; Ricca, E. Expression and display of UreA of Helicobacter acinonychis on the surface of Bacillus subtilis spores. Microb. Cell Fact. 2010, 9, 2. [CrossRef] [PubMed]

31. Permpoonpattana, P.; Hong, H.A.; Phetcharaburanin, J.; Huang, J.M.; Cook, J.; Fairweather, N.F.; Cutting, S.M. Immunization with Bacillus spores expressing toxin A peptide repeats protects against infection with Clostridium difficile strains producing toxins A and B. Infect. Immun. 2011, 79, 2295-2302. [CrossRef] 
32. Ning, D.; Leng, X.; Li, Q.; Xu, W. Surface-displayed VP28 on Bacillus subtilis spores induce protection against white spot syndrome virus in crayfish by oral administration. J. Appl. Microbiol. 2011, 111, 1327-1336. [CrossRef]

33. Youngman, P.; Perkins, J.B.; Losick, R. Construction of a cloning site near one end of Tn917 into which foreign DNA may be inserted without affecting transposition in Bacillus subtilis or expression of the transposon-borne erm gene. Plasmid 1984, 12, 1-9. [CrossRef]

34. Naclerio, G.; Baccigalupi, L.; Zilhao, R.; De Felice, M.; Ricca, E. Bacillus subtilis spore coat assembly requires cotH gene expression. J. Bacteriol. 1996, 178, 4375-4380. [CrossRef]

35. Zilhao, R.; Isticato, R.; Martins, L.O.; Steil, L.; Volker, U.; Ricca, E.; Moran, C.P., Jr.; Henriques, A.O. Assembly and function of a spore coat-associated transglutaminase of Bacillus subtilis. J. Bacteriol. 2005, 187, 7753-7764. [CrossRef] [PubMed]

36. Chen, X.; Katchar, K.; Goldsmith, J.D.; Nanthakumar, N.; Cheknis, A.; Gerding, D.N.; Kelly, C.P. A mouse model of Clostridium difficile-associated disease. Gastroenterology 2008, 135, 1984-1992. [CrossRef] [PubMed]

37. Pizarro-Guajardo, M.; Chamorro-Veloso, N.; Vidal, R.M.; Paredes-Sabja, D. New insights for vaccine development against Clostridium difficile infections. Anaerobe 2019, 58, 73-79. [CrossRef] [PubMed]

38. Sorman, A.; Zhang, L.; Ding, Z.; Heyman, B. How antibodies use complement to regulate antibody responses. Mol. Immunol. 2014, 61, 79-88. [CrossRef] [PubMed]

39. Yu, L.H.; Cutting, S.M. The effect of anti-spore antibody responses on the use of spores for vaccine delivery. Vaccine 2009, 27, 4576-4584. [CrossRef]

40. Lang, M.L.; Shrestha, B. Adaptive immune constraints on C. difficile vaccination. Expert Rev. Vaccines 2017, 16, 1053-1055. [CrossRef]

41. Oggioni, M.R.; Ciabattini, A.; Cuppone, A.M.; Pozzi, G. Bacillus spores for vaccine delivery. Vaccine 2003, 21 (Suppl. 2), S96-S101. [CrossRef]

42. Duc le, H.; Hong, H.A.; Fairweather, N.; Ricca, E.; Cutting, S.M. Bacterial spores as vaccine vehicles. Infect. Immun. 2003, 71, 2810-2818. [CrossRef] [PubMed]

43. Rhee, K.J.; Sethupathi, P.; Driks, A.; Lanning, D.K.; Knight, K.L. Role of commensal bacteria in development of gut-associated lymphoid tissues and preimmune antibody repertoire. J. Immunol. 2004, 172, 1118-1124. [CrossRef] [PubMed]

44. Sibley, L.; Reljic, R.; Radford, D.S.; Huang, J.M.; Hong, H.A.; Cranenburgh, R.M.; Cutting, S.M. Recombinant Bacillus subtilis spores expressing MPT64 evaluated as a vaccine against tuberculosis in the murine model. FEMS Microbiol. Lett. 2014, 358, 170-179. [CrossRef]

45. Wang, J.; Wang, Y.; Zhang, E.; Zhou, M.; Lin, J.; Yang, Q. Intranasal administration with recombinant Bacillus subtilis induces strong mucosal immune responses against pseudorabies. Microb. Cell Fact. 2019, 18, 103. [CrossRef] [PubMed]

46. Tavares Batista, M.; Souza, R.D.; Paccez, J.D.; Luiz, W.B.; Ferreira, E.L.; Cavalcante, R.C.; Ferreira, R.C.; Ferreira, L.C. Gut adhesive Bacillus subtilis spores as a platform for mucosal delivery of antigens. Infect. Immun. 2014, 82, 1414-1423. [CrossRef]

47. Isticato, R.; Ricca, E. Spore Surface Display. Microbiol. Spectr. 2014, 2. [CrossRef] [PubMed]

48. Duc le, H.; Hong, H.A.; Uyen, N.Q.; Cutting, S.M. Intracellular fate and immunogenicity of B. subtilis spores. Vaccine 2004, 22, 1873-1885. [CrossRef]

49. Casula, G.; Cutting, S.M. Bacillus probiotics: Spore germination in the gastrointestinal tract. Appl. Environ. Microbiol. 2002, 68, 2344-2352. [CrossRef]

50. Hoa, T.T.; Duc, L.H.; Isticato, R.; Baccigalupi, L.; Ricca, E.; Van, P.H.; Cutting, S.M. Fate and dissemination of Bacillus subtilis spores in a murine model. Appl. Environ. Microbiol. 2001, 67, 3819-3823. [CrossRef]

51. Gutjahr, A.; Tiraby, G.; Perouzel, E.; Verrier, B.; Paul, S. Triggering Intracellular Receptors for Vaccine Adjuvantation. Trends. Immunol. 2016, 37, 716. [CrossRef]

52. Santos, F.D.S.; Mazzoli, A.; Maia, A.R.; Saggese, A.; Isticato, R.; Leite, F.; Iossa, S.; Ricca, E.; Baccigalupi, L. A probiotic treatment increases the immune response induced by the nasal delivery of spore-adsorbed TTFC. Microb. Cell Fact. 2020, 19, 42. [CrossRef] [PubMed]

53. Harwood, C.R.; Cutting, S.M. Molecular biological methods for Bacillus; Wiley: New York, NY, USA, 1990; 581p. 
54. Calderon-Romero, P.; Castro-Cordova, P.; Reyes-Ramirez, R.; Milano-Cespedes, M.; Guerrero-Araya, E.; Pizarro-Guajardo, M.; Olguin-Araneda, V.; Gil, F.; Paredes-Sabja, D. Clostridium difficile exosporium cysteine-rich proteins are essential for the morphogenesis of the exosporium layer, spore resistance, and affect C. difficile pathogenesis. PLoS Pathog 2018, 14, e1007199. [CrossRef] [PubMed]

55. Edwards, A.N.; McBride, S.M. Isolating and Purifying Clostridium difficile Spores. Methods Mol. Biol. 2016, 1476, 117-128. [CrossRef] [PubMed]

56. Isticato, R.; Ricca, E.; Baccigalupi, L. Spore Adsorption as a Nonrecombinant Display System for Enzymes and Antigens. J. Vis. Exp. 2019. [CrossRef]

57. Warren, C.A.; van Opstal, E.J.; Riggins, M.S.; Li, Y.; Moore, J.H.; Kolling, G.L.; Guerrant, R.L.; Hoffman, P.S. Vancomycin treatment's association with delayed intestinal tissue injury, clostridial overgrowth, and recurrence of Clostridium difficile infection in mice. Antimicrob. Agents Chemother. 2013, 57, 689-696. [CrossRef]

58. Deakin, L.J.; Clare, S.; Fagan, R.P.; Dawson, L.F.; Pickard, D.J.; West, M.R.; Wren, B.W.; Fairweather, N.F.; Dougan, G.; Lawley, T.D. The Clostridium difficile spo0A gene is a persistence and transmission factor. Infect. Immun. 2012, 80, 2704-2711. [CrossRef]

59. Theriot, C.M.; Koumpouras, C.C.; Carlson, P.E.; Bergin, I.I.; Aronoff, D.M.; Young, V.B. Cefoperazone-treated mice as an experimental platform to assess differential virulence of Clostridium difficile strains. Gut Microbes 2011, 2, 326-334. [CrossRef]

(C) 2020 by the authors. Licensee MDPI, Basel, Switzerland. This article is an open access article distributed under the terms and conditions of the Creative Commons Attribution (CC BY) license (http://creativecommons.org/licenses/by/4.0/). 